Analisis Kandungan Mineral ... (Zaroh Irayani dan Bilalodin)

\title{
ANALISIS KANDUNGAN MINERAL BERPOTENSI TINGGI PADA PASIR GALIAN DI WILAYAH KABUPATEN BANYUMAS
}

\author{
Zaroh Irayani dan Bilalodin
}

Program Studi Fisika, Jurusan MIPA, Fakultas Sains dan Teknik, UNSOED, Purwokerto

\begin{abstract}
It have been done analysis high potential mineral contents of sands and sandstone in Banyumas region. Sands and sandstone are taken from mining traditional at rivers and river's stone grinder place. Sand samples were taken from Tajum, Logawa, Serayu and Klawing river, while sandstone were taken from Banjaran, Logawa and Klawing river's grinder place. Sand was separate using permanent magnet to disassociated the magnetic and non magnetic mineral content and analyzed by X-ray difraction to reveal the mineral types. The Result indicated that river sand contained 39\% magnetic mineral and $61 \%$ non magnetic. While identification using X-ray difraction obtained that sand have mineral of complex structured of valuable element such as $\mathrm{Fe}, \mathrm{Ti}, \mathrm{Si}$ and $\mathrm{Zn}$ and also rare earth like Y, Ca, Li and La.
\end{abstract}

Keywords: sand, mineral content, magnetic.

\section{PENDAHULUAN}

Pasir merupakan bahan alam yang banyak tersebar di wilayah Indonesia. Pasir di Pulau Jawa dapat ditemui di daerah pesisir selatan dan sebagian di pantai utara. Pasir di Pulau Jawa juga dapat ditemui di sungai-sungai besar dan kecil. Hingga saat ini, pasir hanya digunakan sebagai bahan pendukung pada pembangunan fisik seperti gedung, jembatan, perumahan dan jalan raya.

Sebagian besar pasir di wilayah selatan Pulau Jawa mengandung mineral besi yang tinggi. Menurut Yulianto, dkk. (2002), pasir besi mempunyai potensi untuk bahan industri baja dan industri semen. Selama ini pasir besi ditambang hanya digunakan sebagai bahan mentah (raw material) dan dijual langsung ke pihak pengguna tanpa melalui pengolahan. Pemanfaatan seperti ini, tentu saja tidak efektif dan optimal, mengingat masih adanya mineral lain yang tidak diperhitungkan, dan mineral tersebut mungkin berpotensi mengandung nilai ekonomi tinggi.

Sebagian mineral-mineral alami yang terkandung di dalamnya mempunyai nilai ekonomi yang tinggi untuk industri, diantaranya: Rutil $\left(\mathrm{TiO}_{2}\right)$ berwarna hitam kemerahan merahan, Ilmerit $\left(\mathrm{FeTiO}_{2}\right)$ berwarna kehitam-hitaman dengan kadar $\mathrm{TiO}_{2}$ antara $45 \%$ hingga 65\%, Leucoxene "highly altered Ilmenit" dengan kadar $\mathrm{TiO}_{2}$ lebih dari $68 \%$, Zirkom $\left(\mathrm{ZrSiO}_{4}\right)$ berwarna agak keputihan dengan kadar $\mathrm{ZrO}_{2}$ antara $45 \%$ hingga 65\%, Monosit $\left(\mathrm{LTJ}_{\mathrm{PO}} \cdot \mathrm{SiO}_{4}\right)$ dengan kadar unsurunsur $\mathrm{Ce}, \mathrm{La}, \mathrm{Th}$, dan $\mathrm{Y}$ antara $55 \%$ hingga 65\%, Xenotim (LTJ.PO 4$)$ dengan kadar logam tanah jarang antara $50 \%$ hingga $60 \%$ dengan kandungan terbesarnya adalah unsur $\mathrm{Y}$ (Itrium). Pasir besi (campuran $\mathrm{Fe}$ dan $\mathrm{TiO}$ ) dengan kadar Ti antara 2\% hingga 12\% (http//www.jatan.org).

Menurut Bijaksana (2002), pasir banyak mengandung mineral-mineral magnetik alami. Secara umum, mineral magnetik dapat dikelompokkan menjadi diamagnetik, paramagnetik dan feromagnetik, termasuk ferimagnetik dan antiferomagnetik. Namun demikian, istilah mineral magnetik, umumnya sering dikonotasikan dari 
kelompok oksida besi. Contoh mineralmineral magnetik yang termasuk keluarga besi-titanium oksida antara lain magnetite $\left(\mathrm{Fe}_{3} \mathrm{O}_{4}\right)$, hematite atau karat $\left(\mathrm{áFe}_{2} \mathrm{O}_{3}\right)$ dan maghemite $\left(\tilde{a} \mathrm{Fe}_{2} \mathrm{O}_{3}\right)$. Contoh mineral magnetik besi dari kelompok sulfide-besi, antara lain pyrite $\left(\mathrm{FeS}_{2}\right)$ dan pyrrhotite $\left(\mathrm{Fe}_{7} \mathrm{~S}_{8}\right)$, sementara yang tergolong hidroksida besi antara lain goethite (áFeOOH). Mineral goethite (áFeOOH) banyak terdapat di daerah lembab. Mineral ini juga dapat dihasilkan dari proses alterasi dari mineral pyrite $\left(\mathrm{FeS}_{2}\right)$ pada batu gamping. Mineral magnetik juga dapat dihasilkan dari proses aktivitas organisme biologi, contohnya adalah bakteri magnetotaktik. Proses aktivitas bakteri ini menghasilkan mineral magnetite berbentuk unik. Magnetite yang dihasilkan dari proses aktivitas bakteri ini berperan penting dalam perolehan magnetoisasi pada sedimen marin.

Kabupaten Banyumas merupakan salah satu daerah di selatan Pulau Jawa yang mempunyai wilayah penambangan pasir yang cukup besar. Pasir bagi masyarakat Kabupaten Banyumas merupakan salah satu komoditas utama bidang pertambangan. Lokasi penambangan pasir di wilayah Kabupaten Banyumas, diantaranya meliputi Kecamatan Patikraja, Kecamatan Jatilawang, Kecamatan Wangon, Kecamatan Rawalo, Kecamatan Gumelar, Kecamatan Karanglewas dan Kecamatan Somagede. Lokasi penambangan pasir juga dapat ditemui di Sungai Serayu, Sungai Logawa, Sungai Klawing, Sungai Tajum, Sungai Banjaran, Sungai Cangkok dan Sungai Krukut (Bappeda Banyumas, 2005). Pasir galian tersebut hingga saat ini, hanya dimanfaatkan sebagai bahan bangunan fisik. Potensi kandungan mineral pada pasir di lokasi penambangan tersebut belum diteliti sehingga belum dapat dimanfaatkan dengan baik.

Oleh karena itu, untuk meningkatkan nilai ekonomi pasir galian di Kabupaten
Banyumas, diperlukan adanya analisis kandungan mineral untuk mengungkap mineral-mineral berpotensi tinggi yang terkandung di dalamnya. Dengan demikian, hasil analisis ini diharapkan dapat bermanfaat, terutama untuk meningkatkan kondisi ekonomi masyarakat di Kabupaten Banyumas melalui pemberdayaan sumberdaya alamnya.

\section{METODE PENELITIAN}

Bahan yang dipakai adalah pasir sungai yang diambil dari Sungai Logawa, Tajum, Klawing dan Serayu serta pasir batu yang diambil dari penggilingan batu dari Sungai Banjaran, Logawa dan Tajum. Peralatan yang digunakan antara lain: magnet, wadah sampel, sekop, ember, set pengujian XRay Diffraction, penumbuk pasir, neraca digital (O-haus), dan gelas ukur.

Prosedur penelitiannya adalah sebagai berikut: pada tahap persiapan dilakukan survei awal di lapangan untuk menentukan titik lokasi pengambilan sampel. Pada tahap pelaksanaan, kegiatan yang dilakukan adalah pengambilan sampel pasir dari lokasi, kemudian dilakukan proses pemisahan (ekstraksi) kandungan bahan-bahan magnetik dari pasirnya dengan magnet. Unsur magnetik dan non magnetiknya diukur massa jenisnya. Komposisi jenisjenis mineral magnetik, diketahui dengan proses karakterisasi dengan peralatan difraksi sinar $\mathrm{X}(X-R D)$. Bagian paling akhir adalah analisis data hasil yang diperoleh dari proses karakterisasi dengan peralatan difraksi sinar $\mathrm{X}(X-R D)$. Sudut-sudut yang memiliki intensitas yang besar ditentukan mineralnya dengan cara membandingkan nilai sudutnya terhadap mineral penyusunnya dengan Handbook of Arranged Mineral by $X$ Ray Powder Diffraction. 


\section{HASIL DAN PEMBAHASAN 1.Karakteristik Fisik Pasir}

Sampel pasir diambil dari lokasi penambangan rakyat dan pengolahan batu kali antara lain di Sungai Serayu, Logawa, Klawing dan Tajum. Pasir yang diperoleh mempunyai karakteristik antara lain berwarna hitam, berbentuk butiran dengan diameter 0,2-0,05 $\mathrm{mm}$. Warna hitam pada pasir besi juga menunjukkan bahwa dalam pasir tersebut mengandung mineral $\mathrm{FeTiO}_{3}$. Hasil pemisahan pasir menggunakan magnet buatan diperoleh $39 \%$ pasir mengandung mineral magnetik dan $61 \%$ non magnetik.

\section{Kerapatan Massa Pasir Magnetik}

Menurut Buckman (1992), nilai kerapatan pasir berkisar antara 1,20 sampai dengan 1,80. Nilai rapat massa pasir ratarata yang diperoleh dari hasil perhitungan dengan menentukan volume dan massa pasir adalah $1,5 \mathrm{~g} / \mathrm{cm}^{3}$. Menurut Hunt (1995), mineral magnetik mempunyai $\left(\mathrm{Mg}, \mathrm{Fe}^{++}\right)_{3} \mathrm{Al}_{4} \mathrm{BeSi}_{3} \mathrm{O}_{16}$ dan Rodalquilarite $\mathrm{H}_{3} \mathrm{Fe}^{+++}{ }_{2}\left(\mathrm{Te}^{++++} \mathrm{O}_{3}\right)_{4} \mathrm{Cl}$. Jenis-jenis mineral yang terdapat dalam pasir Sungai Logawa antara lain: Versiliaite dengan rumus molekul $\mathrm{Fe}^{+2}{ }_{4} \mathrm{Fe}^{+3}{ }_{8} \mathrm{Sb}^{+3}{ }_{12} \mathrm{O}_{23} \mathrm{~S}_{2}$ untuk puncak tertinggi, lalu Stokesite $\mathrm{CaSnSi}_{3} \mathrm{O}_{9} \cdot 2\left(\mathrm{H}_{2} \mathrm{O}\right)$ dan Fayalite $\mathrm{Fe}_{2}^{++} \mathrm{SiO}_{4}$. Jenis-jenis mineral yang terdapat dalam pasir Sungai Serayu antara lain Mgriite $\mathrm{Cu}_{3} \mathrm{AsSe} 3$, Batiferrite $\mathrm{Ba}\left(\mathrm{Ti}_{2} \mathrm{Fe}^{+++}{ }_{8} \mathrm{Fe}^{++}{ }_{2}\right) \mathrm{O}_{19}$ dan Wilhelmkleinite $\mathrm{ZnFe}_{3}^{+++}\left(\mathrm{AsO}_{4}\right)_{2}(\mathrm{OH})_{2}$. Jenis-jenis mineral yang terdapat dalam pasir Sungai Klawing antara lain Tisinalite $\mathrm{Na} 3 \mathrm{H} 3\left(\mathrm{Mn}^{++}, \mathrm{Ca}, \mathrm{Fe}\right) \mathrm{TiSi}_{6}(\mathrm{O}, \mathrm{OH})_{18} \cdot 2\left(\mathrm{H}_{2} \mathrm{O}\right)$ , Tritomite- $(Y)\left(\mathrm{Y}, \mathrm{Ca}, \mathrm{La}, \mathrm{Fe}^{++}\right)_{5}(\mathrm{Si}, \mathrm{B}, \mathrm{Al})_{3}$ $(\mathrm{O}, \mathrm{OH}, \mathrm{F})_{13}, \quad$ dan Cerite- $(\mathrm{La})$ $(\mathrm{La}, \mathrm{Ce}, \mathrm{Ca})_{9}\left(\mathrm{Mg}, \mathrm{Fe}^{+++}\right)\left(\mathrm{SiO}_{4}\right)_{6}\left[\mathrm{SiO}_{3}(\mathrm{OH})\right]($ $\mathrm{OH})_{3}$. Jenis-jenis mineral yang terdapat dalam pasir batu Sungai Banjaran antara lain Versiliaite $\mathrm{Fe}^{++}{ }_{4} \mathrm{Fe}^{+++}{ }_{8} \mathrm{Sb}^{+++}{ }_{12} \mathrm{O}_{23} \mathrm{~S}_{2}$, Valentinite $\mathrm{Sb}_{2} \mathrm{O}_{3}$ dan Teallite $\mathrm{PbSnS}_{2}$. Jenis-jenis mineral yang terdapat dalam rapat massa antara 4,27 sampai 5,26 $\mathrm{g} / \mathrm{cm}^{3}$ sedangkan rapat massa batuan sendimen berkisar antara 1,35 sampai $2,24 \mathrm{~g} / \mathrm{cm}^{3}$. Hasil penentuan rapat massa yang diperoleh jauh lebih kecil dibandingkan dengan mineral magnetik kelompok besi titanium. Rendahnya nilai rapat massa pasir disebabkan mineral penyusun pasir tidak hanya berasal dari keluarga besi titanium oksida akan tetapi berasal dari keluarga diluar besi titanium oksida (Bijaksana, 2002).

\section{Jenis Mineral Penyusun Pasir}

Hasil karakterisasi dengan peralatan $X-R D$ dianalisis kandungan mineralnya. dengan membandingkan nilai sudutnya terhadap mineral penyusunnya dengan Handbook of arranged mineral by X-Ray Powder Diffraction. Jenis-jenis mineral yang terdapat dalam pasir Sungai Tajum antara lain Jeppeite $(\mathrm{K}, \mathrm{Ba})_{2}\left(\mathrm{Ti}, \mathrm{Fe}^{+++}\right)_{6} \mathrm{O}_{13}$, Surinamite

pasir batu Sungai Logawa antara lain Parakuzmenkoite-Fe

$(\mathrm{K}, \mathrm{Ba})_{2} \mathrm{Fe}(\mathrm{Ti}, \mathrm{Nb})_{4}\left(\mathrm{Si}_{4} \mathrm{O}_{12}\right)_{2}(\mathrm{O}, \mathrm{OH})_{4} \cdot 7($

$\left.\mathrm{H}_{2} \mathrm{O}\right)$, Parkerite $\mathrm{Ni}_{3}(\mathrm{Bi}, \mathrm{Pb})_{2} \mathrm{~S}_{2}$ dan

Lamprophyllite

$\mathrm{Na}_{2}(\mathrm{Sr}, \mathrm{Ba})_{2} \mathrm{Ti}_{3}\left(\mathrm{SiO}_{4}\right)_{4}(\mathrm{OH}, \mathrm{F})_{2}$. Jenisjenis mineral yang terdapat dalam pasir batu Sungai Tajum antara lain Ogdianite

$(\mathrm{K}, \mathrm{Na})_{2}\left(\mathrm{Li}, \mathrm{Fe}^{+++}, \mathrm{Al}\right)_{3} \mathrm{ZrSi}_{12} \mathrm{O}_{30}$,

Tritomite- $(Y)\left(\mathrm{Y}, \mathrm{Ca}, \mathrm{La}, \mathrm{Fe}^{++}\right)_{5}(\mathrm{Si}, \mathrm{B}, \mathrm{Al})_{3}$ $(\mathrm{O}, \mathrm{OH}, \mathrm{F})_{13}$, dan Hematite $\mathrm{Fe}_{2} \mathrm{O}_{3}$.

\section{KESIMPULAN}

Pasir yang berasal dari penambangan rakyat di wilayah Kabupaten Banyumas memiliki karakteristik fisik berwarna hitam dan mengandung $39 \%$ mineral magnetik dan $61 \%$ non magnetik. Berdasarkan analisis XRD menunjukkan pasir mengandung mineral komplek yang tersusun atas unsur unsur yang berharga 
seperti Fe,Ti, Si dan Zn serta lagam tanah jarang seperti Y,Ca, Li dan La.

\section{DAFTAR PUSTAKA}

Bappeda Banyumas. 2004. Potensi Kabupaten Banyumas Dalam Rangka Pengembangan Wilayah. Lokakarya Penelitian dan Pengembangan Sumber Daya Lokal untuk Mewujudkan Pembangunan Berkelanjutan dalam Otonomi Daerah.

Bijaksana, S. 2002. Analisa Mineral Magnetik dalam Masalah Lingkungan. Jurnal Geofisik, (1) : 19-27.
Buckman, H., Brady, N. 1969. Ilmu Tanah. Terjemahan oleh Soegiman. Bhratara Karya Aksara. Jakarta.

Yulianto, A., Bijaksana, S., Loeksmanto, W. 2002. Karakterisasi Magnetik dari Pasir Besi Cilacap. Jurnal Fisika Himpunan Fisika Indonesia, Vol A5 (0527).

http://www.jatan.org/indonesia/hauslett er/uploded/pg 32. htm. diakses tahun 2005. 